\title{
Grid Integration Issues for Large Scale Wind Power Plants (WPPs)
}

Wu, Qiuwei; Xu, Zhao; Østergaard, Jacob

Published in:

IEEE Power and Energy Society General Meeting 2010

Link to article, DOI:

10.1109/PES.2010.5589952

Publication date:

2010

Document Version

Publisher's PDF, also known as Version of record

Link back to DTU Orbit

Citation (APA):

Wu, Q., Xu, Z., \& Østergaard, J. (2010). Grid Integration Issues for Large Scale Wind Power Plants (WPPs). In IEEE Power and Energy Society General Meeting 2010 IEEE. https://doi.org/10.1109/PES.2010.5589952

\section{General rights}

Copyright and moral rights for the publications made accessible in the public portal are retained by the authors and/or other copyright owners and it is a condition of accessing publications that users recognise and abide by the legal requirements associated with these rights.

- Users may download and print one copy of any publication from the public portal for the purpose of private study or research.

- You may not further distribute the material or use it for any profit-making activity or commercial gain

- You may freely distribute the URL identifying the publication in the public portal

If you believe that this document breaches copyright please contact us providing details, and we will remove access to the work immediately and investigate your claim. 


\title{
Grid Integration Issues for Large Scale Wind Power Plants (WPPs)
}

\author{
Qiuwei Wu, Member, IEEE, Zhao Xu, Member, IEEE and Jacob Østergaard, Senior Member, IEEE
}

\begin{abstract}
The penetration level of wind power into the power system over the world have been increasing very fast in the last few years and is still keeping the fast growth rate. It is just a matter of time that the wind power will be comparable to the conventional power generation. Therefore, many transmission system operators (TSOs) over the world have come up the grid codes to request the wind power plants (WPPs) to have more or less the same operating capability as the conventional power plants. The grid codes requirements from other TSOs are under development. This paper covers the steady state operation and low voltage ride through (LVRT) for the WPPs. The discussion of coping with the grid codes requirements is presented to come up with the grid codes complied WPPs solutions.
\end{abstract}

Index Terms - Wind Power, Transmission System Operators (TSOs), Grid Codes, Wind Power Plants (WPPs), Grid Integration Issues, PQ Capability, Low Voltage Ride Through, Voltage Control, Frequency Control

\section{INTRODUCTION}

$\mathrm{T}$ he wind power capacity over the world has achieved a dramatic growth in the last few years. Till the end of 2008 , the installed wind power capacity of the whole world reaches 121,188 MW, out of which 27,261 MW was installed in 2008 [1]. The new installed wind power capacity from 1998 to 2008 is illustrated in Figure 1. The US installed a record 8.4 $\mathrm{GW}$ in 2008 and became the number one in terms of the total installed wind power capacity for the first time. China doubled its installed capacity in 2008 again and has more than $12 \mathrm{GW}$ installed wind power capacity. European wind power industry continues to broaden and deepen.

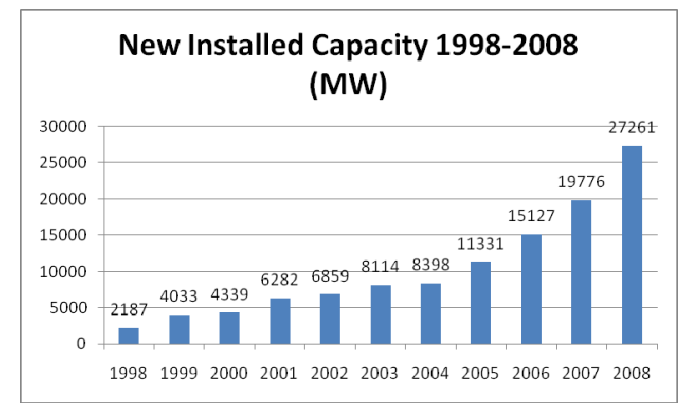

Figure 1 New Installed Wind Power Capacity from 1998 to 2008

Center for Electric Technology, Technical University of Denmark, Elektrovej, DTU - Building 325 Kgs. Lyngby, DK - 2800 ( qw@elektro.dtu.dk ).
With the rapid growth of installed wind power capacity, the wind power is going to have a big share of the whole system installed capacity. The wind power will have a big impact on the system steady state and dynamic operation. In the past time, the wind power plants (WPPs) are allowed to be disconnected under system disturbances. But with the high penetration of wind power into the power systems, the disconnection of WPPs will make it difficult for the system to withstand the system disturbances. Therefore, the grid codes have specified the requirements for the WPPs under the steady state and dynamic conditions. The WPPs have to have the voltage and frequency regulation capabilities under the steady state condition. Under the specified voltage dip conditions caused by the faults within the grid, the WPPs have to stay connected and to fulfill the recovery requirements.

The analysis of large scale integration of wind power in Europe was carried out in [3] regarding the power and energy balancing, grid connection and system stability, grid infrastructure extension and reinforcement, power system adequacy, market design, demand side management and storage. In the end, the recommendations for the power system operation with high amount of wind power were presented. The main problems regarding connecting wind farms to the grid were reviewed in [4] and the suggestions for the amendment of the grid codes were presented in order to integrate the wind power to the power systems without affecting the quality and stability of the system. The analysis of the grid codes of Canada, Denmark, Ireland, Scotland, Germany and UK was implemented in [5] regarding the technical requirements for integrating the wind power to the grid.

In this paper, a more comprehensive review of the grid codes was carried out with the latest grid codes and detailed discussions were implemented to come out the grid codes complied WPP solution.

\section{Steady State Operation ReQuirements}

Basically, the steady state operation requirements comprise power factor requirement, voltage operating range, frequency operating range and voltage quality. Normally, the steady state operation requirements for the WPPs are specified at the point of connection (POC).

\section{1) Reactive Power/Power factor Requirement}

The power factor regulation concerns the reactive power capability of the WPPs within the specified voltage range at the POC under the steady state condition. With the development of the wind turbine technology, the doubly fed induction generator (DFIGs) based wind turbine has both 
inductive and capacitive reactive power capabilities as per the active power output. The reactive power can be consumed or supplied by the grid side converter. For the full scale converter wind turbine, the range of reactive power capability is bigger because of the increased rating of the grid side converter.

The requirements for the reactive power and the power factor are similar in the different Grid Codes. The specific requirements are illustrated in Table 1.

Table 1 Reactive Power/Power factor Requirement

\begin{tabular}{|c|c|}
\hline $\begin{array}{l}\text { Country or } \\
\text { Region }\end{array}$ & PF requirements \\
\hline UK & 0.95 lagging to 0.95 leading [6] \\
\hline Scotland & $\begin{array}{l}\text { from } 100 \% \text { production to } 50 \% \text { production, the } \\
\text { reactive power is requested to be }-32.87 \% \text { to } \\
+32.87 \% \text { of the rated } \mathrm{MW} \text {, from } 50 \% \text { production to } \\
20 \% \text { production, it is requested to be from }-32.87 \% \\
\text { to }-12 \% \text { for the leading part and at }+32.87 \% \text { of the } \\
\text { rated } \mathrm{MW} \text {, from } 20 \% \text { production to } 0 \% \text { production, it } \\
\text { is requested to be }-5 \% \text { to }+5 \% \text { of the rated } \mathrm{MW}[7]\end{array}$ \\
\hline Ireland & $\begin{array}{l}0.95 \text { lagging to } 0.95 \text { leading at full production, } \\
32.6 \mathrm{MVAr} \text { per } 100 \mathrm{MW} \text { installed for active capacity } \\
\text { from } 100 \% \text { production to } 50 \% \text { production, } 0.95 \\
\text { lagging to } 0.95 \text { leading from } 50 \% \text { production to idle } \\
\text { [8] }\end{array}$ \\
\hline Germany & $\begin{array}{l}0.95 \text { lagging to } 0.95 \text { leading for a rated active power } \\
\text { capacity }<100 \mathrm{MW}, \text { For a rated active power capacity } \\
>100 \mathrm{MW} \text { the power factor is voltage dependent [9] }\end{array}$ \\
\hline Denmark & $\begin{array}{l}\mathrm{Q} / \text { Prated }=0 \text { to } \mathrm{Q} / \text { Prated }=0.1 \text { at full production and } \\
\text { through a straight line to } \mathrm{Q} / \text { Prated }=-0.1 \text { to } \mathrm{Q} / \text { Prated } \\
=0 \text { at zero production }[10,11]\end{array}$ \\
\hline Spain & 0.98 leading to 0.98 lagging without any penalty [12] \\
\hline Sweden & the reactive exchange can be regulated to zero [13] \\
\hline US & 0.95 leading to 0.95 lagging [14] \\
\hline Quebec & $\begin{array}{l}\text { the generator facilities must be designed to supply or } \\
\text { absorb at the generating unit outlet (system side) the } \\
\text { reactive power that corresponds to an overexcited or } \\
\text { under excited rated power factor equal to or less than } \\
0.95 \text {. The reactive power must be available over the } \\
\text { entire active power generation range [15] }\end{array}$ \\
\hline Alberta & 0.90 lagging to 0.95 leading [16] \\
\hline China & 0.97 lagging to 0.97 leading [17] \\
\hline Australia & $\begin{array}{l}\text { Constant power factor mode: } 100 \% \text { power at } \mathrm{PF}_{\text {ind }}= \\
1.0 \text { and } \mathrm{PF}_{\text {cap }}=0.95 ; 50 \% \text { power at } \mathrm{PF}_{\text {ind }}=1.0 \text { and } \\
\mathrm{PF}_{\text {cap }}=0.95[18]\end{array}$ \\
\hline
\end{tabular}

The grid codes specified reactive power and power factor requirements in UK, Sweden, Denmark, US, Alberta, Quebec and China are very straightforward. The WPPs are requested to be able to operate within the area specified by the inductive and capacitive power factor.

The reactive power requirement in Scotland is quite complex which is illustrated in Figure 2. From $100 \%$ to $50 \%$ active power production, the WPPs are requested to have reactive power capability from $-32.87 \%$ to $+32.87 \%$ of the rated $\mathrm{MW}$, from $50 \%$ to $20 \%$ active power production, the range of the reactive power requirement is from $-32.87 \%$ to $12 \%$ for the leading part to $+32.87 \%$ of the rated $\mathrm{MW}$, from $20 \%$ to $0 \%$ active power production, it is requested to be $-5 \%$ to $+5 \%$ of the rated MW.
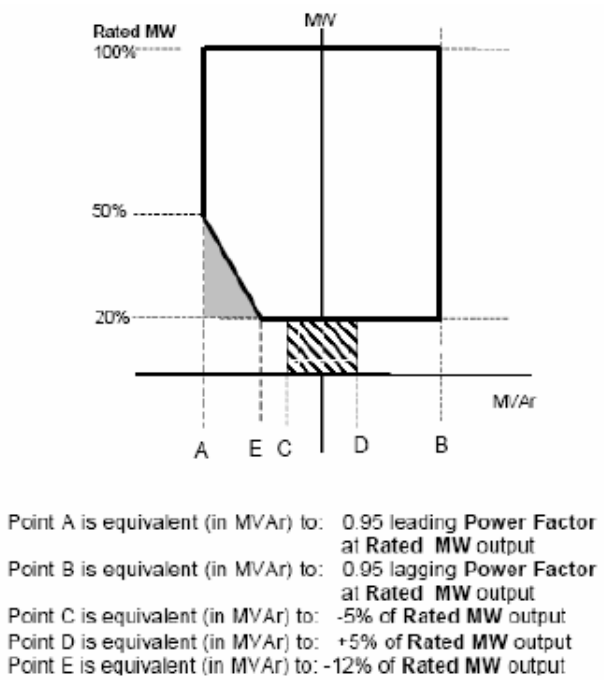

Figure 2 Reactive Power Requirement in Scotland [7]

The reactive power requirement in Ireland is illustrated in Figure 3 . From $100 \%$ to $50 \%$ active power production, the WPPs are requested to have reactive power capability from $32.87 \%$ to $+32.87 \%$ of the rated $\mathrm{MW}$, from $50 \%$ to $0 \%$ active power production, the range of the reactive power requirement is to be within the range of 0.835 inductive power factor to 0.835 capacitive power factor, from $10 \%$ to $0 \%$ active power production, the black area indicates that the reactive power has to be adjusted as per the voltage limits.

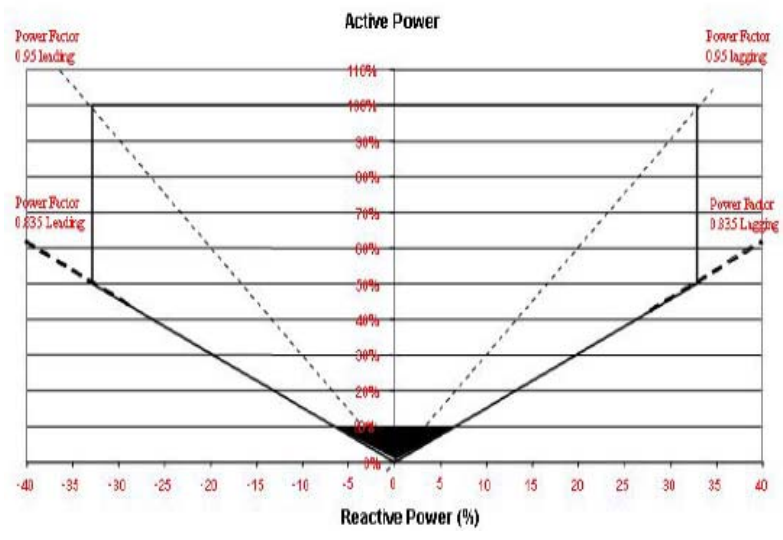

Figure 3 Reactive Power Requirement in Ireland [8]

For the WPPs in Germany, the reactive power requirements consist of two parts. For WPPs with size less than $100 \mathrm{MW}$, the reactive power requirement is same as the one in other grid codes which requests the WPPs can operate within the range specified by 0.95 inductive power factor to 0.95 capacitive power factor. But for the WPPs with size over $100 \mathrm{MW}$, the reactive power requirement is voltage dependent. The reactive power requirements for WPPs with size over $100 \mathrm{MW}$ are illustrated in Figure 4. It is shown that when the voltage at the POC increases from the minimum operating level to the voltage with full power factor range, the power factor range changes from the capacitive part of 0.925 to 0.95 to the full power factor range of 0.95 inductive to 0.925 capacitive, the middle part is the voltage range with the full power factor requirement, when the voltage at the POC is above the 
maximum voltage with full power factor requirement, the power factor requirement is moving to the left, at the maximum operating voltage, the power requirement is reduced to inductive power factor of 0.95 to 1.0 .

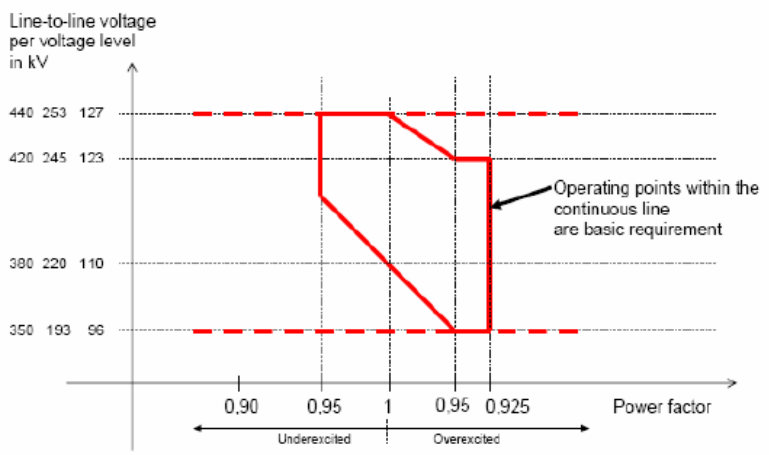

Figure 4 German power factor requirements for $\mathrm{P}_{\text {rated }}$ above 100MW [9]

In order to fulfill the reactive power and power factor requirements at the $\mathrm{POC}$, it is recommended to use the reactive power capability of the wind turbine generators (WTGs) as much as possible.

The reactive power capability of the DFIG based and full scale converter wind turbine increases when the active power output decreases from the $100 \%$ active power output to a specified active power output. After the specified active power level, the reactive power capability of wind turbines will keep the maximum reactive power capability within a range of active power output level. When the active power output of the wind turbine is lower than the minimum active power level with the maximum reactive power, the reactive power capability of the wind turbines is kept in the range specified by an inductive power factor and a capacitive power factor.

Therefore, in order to ensure that WPPs can fulfill the reactive power requirements throughout the range of active power output range of WTGs, the power flow study at the $100 \%$ active power output is needed to be carried out. In most cases, it is good enough for the requirement within the range specified an inductive power factor and a capacitive power factor. If the reactive power requirement range at low active power output level is quite big, it is advised to carry out power flow study at the low active power output to check the power factor requirement compliance.

If the WPPs can not fulfill the reactive power requirements, the shunt reactive power compensation equipments are needed to install at the MV side of the substation of the WPPs. If the POC is far from the substation of the WPPs, it is advised to install reactive power compensation equipments at the busbar of the POC too. The size of the reactive power compensation equipments can be determined by implementing the power flow study with the specified voltage operating range and the power factor range at the POC.

2) Continuous Voltage Operating Requirement

The continuous voltage operating requirements are illustrated in Table 2.
Table 2 Voltage Operating Requirement

\begin{tabular}{|l|l|}
\hline $\begin{array}{l}\text { Country or } \\
\text { Region }\end{array}$ & Voltage operating requirement \\
\hline UK & $\begin{array}{l}132 \mathrm{kV} \text { and } 275 \mathrm{kV} \pm 10 \% \\
400 \mathrm{kV}-10 \% \text { to }+5 \%[6]\end{array}$ \\
\hline Scotland & $\begin{array}{l}132 \mathrm{kV} \text { and } 275 \mathrm{kV} \pm 10 \% \\
400 \mathrm{kV} \pm 5 \%[7]\end{array}$ \\
\hline \multirow{3}{*}{ Ireland } & $110 \mathrm{kV}-10 \%$ to $+12 \%$ \\
& $220 \mathrm{kV}-9 \%$ to $+12 \%$ \\
& $400 \mathrm{kV}-13 \%$ to $+5 \%[8]$ \\
\hline \multirow{3}{*}{ Germany } & $110 \mathrm{kV}-13 \%$ to $+12 \%$ \\
& $220 \mathrm{kV}-13 \%$ to $+12 \%$ \\
& $400 \mathrm{kV}-8 \%$ to $+10 \%[9]$ \\
\hline & $132 \mathrm{kV}-5 \%$ to $+10 \%$ \\
Denmark & $150 \mathrm{kV}-3 \%$ to $+13 \%$ \\
\hline Spain & $400 \mathrm{kV}-10 \%$ to $+5 \%[10,11]$ \\
\hline Sweden & $132 \mathrm{kV} \pm 10 \%[12]$ \\
\hline US & $-10 \%$ to $+5 \%[13]$ \\
\hline Quebec & $\pm 10 \%[14]$ \\
\hline Alberta & $\pm 10 \%[15]$ \\
\hline China & Provided by TSO $[16]$ \\
\hline Australia & $-3 \%$ to $+7 \%[17]$ \\
\hline
\end{tabular}

The WPPs are requested to be able to operate under the condition when the voltage at the POC is within the continuous operating voltage range.

The reactive power requirement must be coordinated with the voltage control. It must be ensured that when the voltage at the POC is within the specified continuous operating voltage range, the voltages inside the WPPs have to be within the operating voltage range of the electrical equipments. Normally, the operating voltage range of the electrical equipments inside the WPPs is 0.9 to $1.1 \mathrm{pu}$.

Sometimes, it is difficult to maintain both the voltage operating requirement and the reactive power requirement due to the topology of the WPPs and the grid conditions. It is advised for the WPP owner to liaise with the TSO for a reduced reactive power requirement or a voltage dependent reactive power requirement.

\section{3) Frequency Operating Requirement}

The frequency operating requirements for the WPPs specified in the reviewed grid codes are illustrated in Table 3.

Table 3 Frequency Operating Requirement

\begin{tabular}{|l|l|}
\hline $\begin{array}{l}\text { Country or } \\
\text { Region }\end{array}$ & PF requirements \\
\hline UK & $\begin{array}{l}\text { Continuous operating range } 47.5-52 \mathrm{~Hz} \\
\text { 20 Sec. }<47.5 \mathrm{~Hz}[6]\end{array}$ \\
\hline Scotland & $\begin{array}{l}\text { Continuous operating range } 47.5-52 \mathrm{~Hz} \\
\text { 20 Sec. }<47.5 \mathrm{~Hz}[7]\end{array}$ \\
\hline Ireland & $\begin{array}{l}\text { Continuous operating range } 49.5-50.5 \mathrm{~Hz} \\
60 \text { Min. } 50.5-52.0 \mathrm{~Hz} \text { and } 49.5-47.5 \mathrm{~Hz} \\
\text { 20 Sec. }<47.5 \mathrm{~Hz}[8]\end{array}$ \\
\hline Germany & Continuous operating range $47.5-51.5 \mathrm{~Hz}[9]$ \\
Denmark & $\begin{array}{l}\text { Continuous operating range } 49.5-50.5 \mathrm{~Hz} \\
\text { 30 Min. 50.5-52.0 Hz and 49.5-47.5 Hz } \\
\text { 3 Min. 47.0-47.5 Hz [10,11] }\end{array}$ \\
\hline Spain & Continuous operating range $49.5-50.5 \mathrm{~Hz}[12]$ \\
\hline Sweden & $\begin{array}{l}\text { Continuous operating range } 49.0-51.0 \mathrm{~Hz} \\
>30 \text { Min. 51.0-52.0 Hz and 47.5-49.0 Hz [13] }\end{array}$ \\
\hline US & Not specified $[14]$ \\
\hline & $\begin{array}{l}\text { Continuous operating range } 59.4-60.6 \mathrm{~Hz} \\
11 \text { Min. } 58.5-59.4 \mathrm{~Hz} \text { and } 60.6-61.5 \mathrm{~Hz}\end{array}$ \\
Quebec & $\begin{array}{l}1.5 \mathrm{Min} .57 .5-58.5 \mathrm{~Hz} \text { and } 61.5-61.7 \mathrm{~Hz} \\
10 \text { Sec. } 57.0-57.5 \mathrm{~Hz}\end{array}$ \\
\hline
\end{tabular}




\begin{tabular}{|l|l|}
\hline & 2 Sec. $56.5-57.0 \mathrm{~Hz}$ \\
& 0.35 Sec. $55.5-56.5 \mathrm{~Hz}$ \\
& Instantaneous $<55.5 \mathrm{~Hz}$ or $>=61.7 \mathrm{~Hz}[15]$ \\
\hline Alberta & Refer to WECC requirement $[16]$ \\
\hline \multirow{3}{*}{ China } & Continuous operating range $49.5-50.5 \mathrm{~Hz}$ \\
& $>2$ Min. $50.5-51.0 \mathrm{~Hz}$ \\
& $>10$ Min. $48.0-49.5 \mathrm{~Hz}[17]$ \\
\hline Australia & Continuous operating range $47.0-52.0 \mathrm{~Hz}[18]$ \\
\hline
\end{tabular}

Normally, the TSOs request the WPPs has the ability for the primary frequency control.

4) Voltage Quality

The assessment of the impact of the WPPs on the voltage quality shall be based on the concepts below.

- Rapid voltage changes or voltage jumps

- Voltage fluctuations and flicker

- Harmonics

In most of the grid codes, the voltage quality requirements are specified by referring to the corresponding IEEE and IEC standards.

The Grid Codes from UK [6] and Scotland [7] refer to the standard ER G5/4 - "Planning Levels for Harmonic Voltage Distortion and the Connection of Non-Linear Loads to the transmission systems and Public Electricity Supply Systems in the United Kingdom". IEC 61000-3-6 "Electromagnetic compatibility (EMC) - Part 3-6: Limits - Assessment of emission limits for the connection of distorting installations to MV, HV and EHV power systems" and IEC 61000-3-7 "Electromagnetic compatibility (EMC) - Part 3-7: Limits Assessment of emission limits for the connection of fluctuating installations to MV, HV and EHV power systems" are referred in the Irish Grid Codes regarding the harmonics, the voltage fluctuation and the flicker.

The Canadian Grid Code [16] refers to the IEEE standard 519-1992 "Recommended Practices and Requirements for Harmonic Control in Electrical Power Systems". The Chinese Grid Code [17] refers to the GB/T 14549-1993 "Quality of Electric Energy Supply Harmonics in public supply Network" and GB 12326-2000 "Power quality Voltage fluctuation and flicker".

The requirements of the mentioned standards are not included in the paper.

In the Danish Grid Code, the specific requirements on voltage quality are defined. The detailed requirements are presented below.

Rapid voltage changes $[10,11]$

- General constraint $<3.0 \%$

- Until a frequency of 10 per hour $<2.5 \%$

- Until frequency of 100 per hour $<1.5 \%$

Voltage variations and flicker

- $\mathrm{P}_{\mathrm{st}}<0.30$

- $\mathrm{P}_{\mathrm{lt}}<0.20$

Harmonic voltages

- $\mathrm{D}_{\mathrm{n}}<1 \%$ for $1<\mathrm{n}<51$

- $\mathrm{THD}<1.5 \%$

In the rest of the reviewed grid codes, the voltage quality requirements are not mentioned. But the requirements in the IEC or IEEE standard(s) have to be applied.
If the voltage quality of the WPPs can not meet the grid code requirements, the active filters can be used to reduce the voltage distortion.

\section{LOW VolTage RIDE Through (LVRT) REQUiREMENT}

The LVRT requirements for the WPPs refer to the WPPs' capability to stay connected under the specified low voltage conditions at the POC caused by the faults within the grid. In some grid codes, the WPPs are also requested to supply maximum reactive current during the specified low voltage conditions. In the mean time, some grid codes also specify the post fault active power recovery requirement. The specified low voltage conditions at the POC in the reviewed grid codes are illustrated in Table 4.

Table 4 Grid Codes Specified LVRT Requirement [6-18]

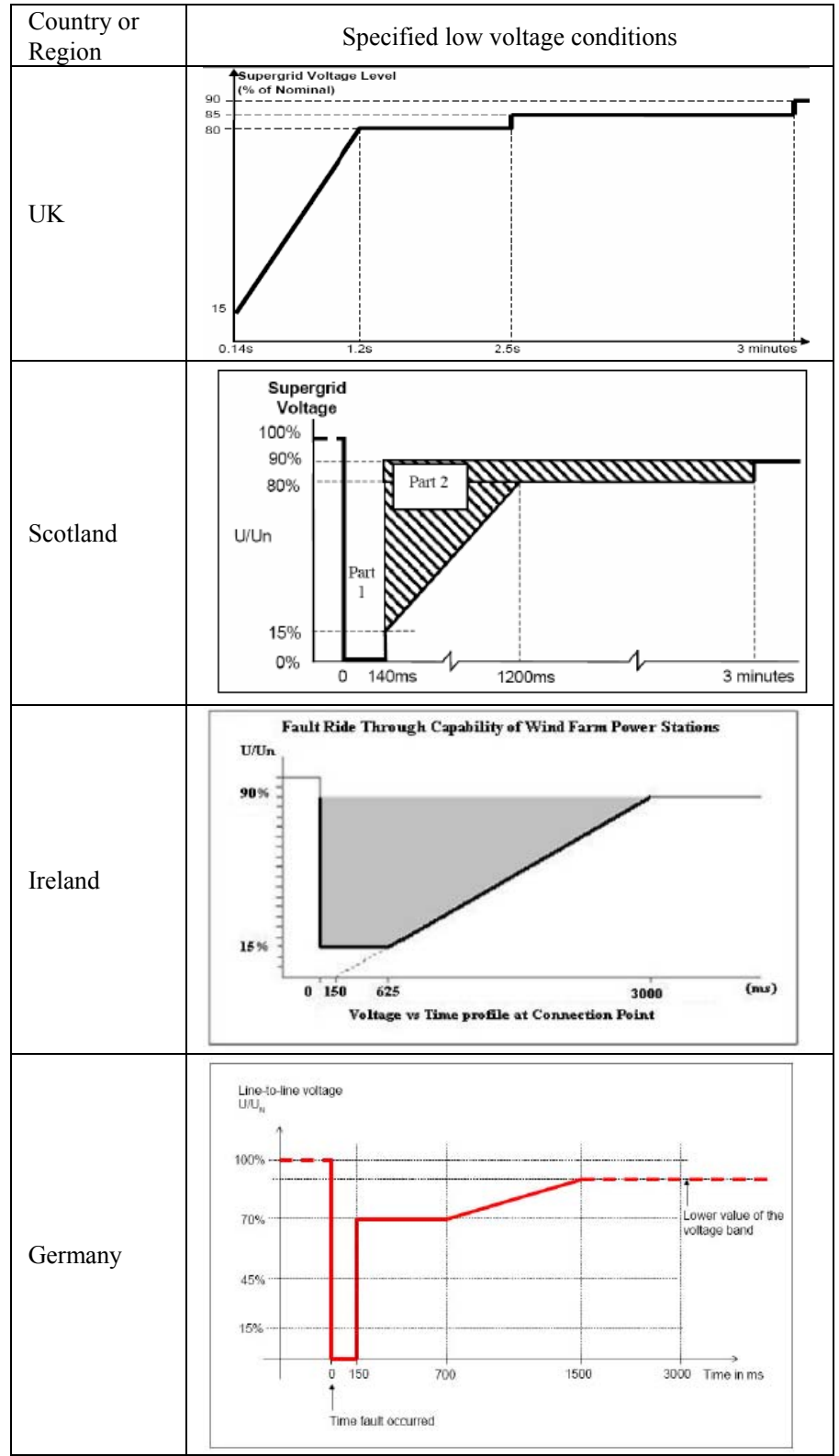



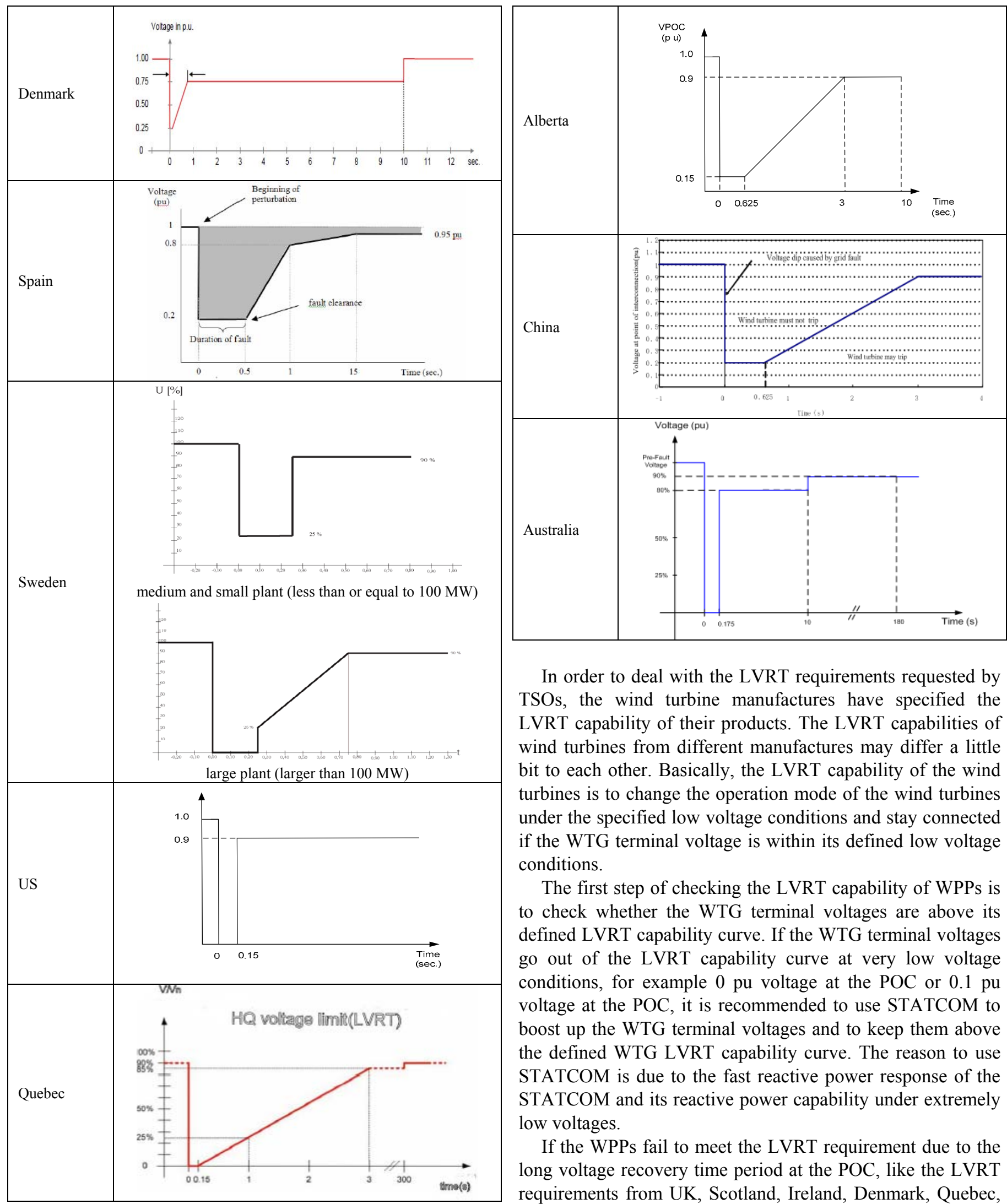

In order to deal with the LVRT requirements requested by TSOs, the wind turbine manufactures have specified the LVRT capability of their products. The LVRT capabilities of wind turbines from different manufactures may differ a little bit to each other. Basically, the LVRT capability of the wind turbines is to change the operation mode of the wind turbines under the specified low voltage conditions and stay connected if the WTG terminal voltage is within its defined low voltage conditions.

The first step of checking the LVRT capability of WPPs is to check whether the WTG terminal voltages are above its defined LVRT capability curve. If the WTG terminal voltages go out of the LVRT capability curve at very low voltage conditions, for example $0 \mathrm{pu}$ voltage at the POC or $0.1 \mathrm{pu}$ voltage at the POC, it is recommended to use STATCOM to boost up the WTG terminal voltages and to keep them above the defined WTG LVRT capability curve. The reason to use STATCOM is due to the fast reactive power response of the STATCOM and its reactive power capability under extremely low voltages.

If the WPPs fail to meet the LVRT requirement due to the long voltage recovery time period at the POC, like the LVRT requirements from UK, Scotland, Ireland, Denmark, Quebec, Alberta and china, the mechanically switched capacitor banks (MSC) can be used to boost up the WTG terminal voltages and to keep them above the WTG LVRT capability curve.

Some grid codes also specify the reactive current requirement under the low voltage conditions at the POC. The 
reactive current requirement under low voltage conditions from Spain is illustrated in Figure 5.

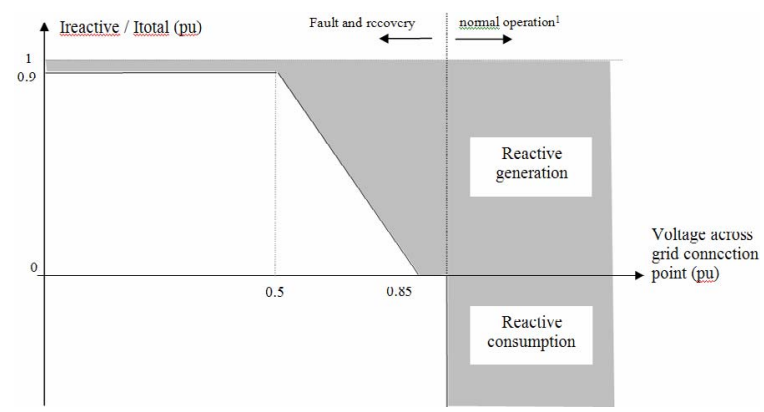

Figure 5 Reactive Current Requirement under Low Voltage Conditions from Spanish Grid Code [12]

It is shown that when the voltage at the POC is less than $0.5 \mathrm{pu}$, the WPPs are requested supply at least 0.9 pu reactive current. When the voltage at the POC is less than $0.85 \mathrm{pu}$, the reactive current from the WPPs is the result of the difference between $0.85 \mathrm{pu}$ and the actual pu voltage at the POC timing 2.57 .

Some grid codes also specify the active power recovery time after the fault. In the Irish Grid Code, the active power recovery time requirement is stated as the one below.

"WTG must be able to provide at least $90 \%$ of its max active power within 1 second of the system voltage recovering to the normal operating range."

The active power of the WPPs has to be checked after the low voltages conditions are cleared.

\section{CONCLUSIONS}

The grid integration issues for large scale WPPs are reviewed in this paper. The steady state operation requirements specified by grid codes, like the reactive power requirement, voltage operating requirement, frequency operating requirement and voltage quality requirement, are discussed. The correlation between the reactive power requirement and the voltage operating requirement is analyzed and the suggestion to meet both requirements is presented. The dynamic LVRT requirement is also analyzed. The suggestion for the WPPs meeting the LVRT requirements is also presented.

\section{REFERENCES}

[1] World Wind Energy Association, World Wind Energy Report 2008, www.wwindea.org.

[2] Global Wind Energy Council, Global Wind 2008 Report, www.gwec.net.

[3] European Wind Energy Association, Large Scale Integration of Wind Energy in the European Power Supply: Analysis, Issues and Recommendations, Dec. 2005, www.ewea.org.

[4] Inigo Martinez de Alegria, Jon Andreua, Jose Luis Martina, Pedro Ibanez, Jose Luis Villateb and Haritza Camblong, "Connection requirements for wind farms: A survey", Renewable and Sustainable Energy Reviews, No. 11, 2007, pp. 1858-1872.

[5] Willi Christiansen and David T. Johnsen, Analysis of requirements in selected Grid Codes, Ørsted DTU, Section of Electric power Engineering, Technical University of Denmark (DTU).

[6] National Grid Electricity Transmission plc, "The Grid Code", 24 Jun. 2009, www.nationalgrid.com.
[7] ScotishPower, "Scotish Grid Code", Nov. 2002, www.scotishpower.com

[8] EirGrid, "EirGrid Grid Code V3.4", 16 Oct. 2009 www.eirgrid.com.

[9] E.ON Netz GmbH, Grid Code - High and extra high voltage, 1 Apr. 2006, www.eon.com.

[10] Energine.dk, "EnergiGrid connection of wind turbines to networks with voltages below $100 \mathrm{kV}$ ", 19 May 2004, www.energinet.dk.

[11] Energine.dk, "EnergiGrid connection of wind turbines to networks with voltages above $100 \mathrm{kV}$ ", Nov. 2004, www.energinet.dk.

[12] RED Electrica De Espana, "PO 12.3. Requisitos de respuesta frente a huecos de tension de las instalaciones de produccion de regimen especial", Nov. 2005, www.depeca.uah.es.

[13] Svenska Kraftna, "SvKFS 2005:2 Driftsäkerhetsteknisk utformning av produktionsanläggningar", 9 Dec. 2005, www.svk.se.

[14] Federal Energy Regulatory Commission, USA, "Interconnection for Wind Energy", 12 Dec. 2005, www.ferc.gov.

[15] Hydro Quebec Transenergie, "Transmission Provider Technical Requirements for the Connection of Power Plants to the HydroQuebec Transmission System", Mar. 2006, www.hydroquebec.com/transenergie.

[16] Alberta Electric System Operator, Canada, "Wind power facility technical requirements, Rev. 0", 30 Nov. 2004, www.aeso.ca.

[17] China Electric Power Research Institute, "Technical Rule for Connecting Wind Farm into Power Network", Mar. 2009, www.epri.ac.cn.

[18] Australian Energy Market Commission, "National Electricity Amendment (Technical Standards for wind and other generators connections) Rule 2007”, 8 Mar. 2007, www.aemc.gov.au. 